\title{
DISTRIBUTION OF ARSENIC AND MERCURY IN THE AQUATIC ECOSYSTEM OF THE FIVE CHILEAN RESERVOIRS
}

\author{
SYLVIA. V. COPAJA ${ }^{1 *}$,VESNA. R. NUNEEZI AND DAVID E. VÉLIZ ${ }^{2,3}$ \\ ${ }^{1}$ Departamento de Química, ${ }^{2}$ Departamento de Ciencias Ecológicas, ${ }^{3}$ Nucleo Milenio de Ecología y Manejo Sustentable de Islas Oceánicas (ESMOI). \\ Facultad de Ciencias. Universidad de Chile. Casilla 653 Ñuñoa, Santiago, Chile.
}

\begin{abstract}
Arsenic and mercury are among the metals and metalloids more toxic to the ecosystem. A quantification method by atomic absorption spectroscopy with hydride generator (AAS-HG) to determine total As and cold steam to determine Hg was optimized and validated in various matrices: superficial water, interstitial or pore water, sediments and in gill, liver and muscle of two fish species, a silverside (Basilichthys microlepidotus) and a catfish (Trichomycterus areolatus). The quality of the results was tested using certified reference materials (Water: ERM-CA615; Fish: DOLT-4; Sediment: BCR-320R). Samples were collected in the affluent and effluent of five reservoirs: Cogotí ( $\left.31^{\circ} 00^{\prime} \mathrm{S}, 71^{\circ} 05^{\prime} \mathrm{W}\right)$; Corrales $\left(31^{\circ} 54^{\circ} \mathrm{S}, 70^{\circ} 54^{\prime} \mathrm{W}\right)$; La Paloma $\left(30^{\circ} 44^{\prime} \mathrm{S}, 71^{\circ} 00^{\prime} \mathrm{W}\right)$; Rapel ( $\left.34^{\circ} 08^{\prime} \mathrm{S}, 71^{\circ} 29^{\prime} \mathrm{O}\right)$; Recoleta (30 $\left.28^{\prime} \mathrm{S}, 71^{\circ} 06^{\prime} \mathrm{W}\right)$. ), in two campaigns during high flow (winter 2010) and low flow (summer 2011).

The results show a clear difference in the distribution of $\mathrm{As}$ and $\mathrm{Hg}$ in the different matrices; higher concentrations were found in the order sediment $>$ interstitial water $>$ surface water. Catfish showed higher accumulation of both metals, and metal concentrations generally decreased in the order liver $>$ gill $>$ muscle. No significant effect of reservoirs and zones was observed in As and $\mathrm{Hg}$ content. However, Arsenic (As) was found in higher concentration in the different matrices of the five reservoirs and zones. The concentrations of As and $\mathrm{Hg}$ in all samples did not exceed international standards in the case of sediment and the Chilean norm in the case of water, while in both fish species concentrations of As and $\mathrm{Hg}$ in muscle exceeded international standards.
\end{abstract}

Keywords: arsenic, mercury, HG-AAS, sediments, fish, reservoirs.

\section{INTRODUCTION}

Metal water analysis has been demonstrated to be inefficient at identifying metal inputs to fluvial systems because of the inherent variability of flow and contaminant concentrations. However, sediment has been considered as the largest reservoir of metal in aquatic systems ${ }^{1,2}$. Sediment may be a good indicator of the global status of the fresh water system to evaluate the relationship between ecological status, pollutant concentrations and pore water and sediment eco-toxicity ${ }^{3}$. Sediments have been found to be a reservoir of most metals released into rivers; some elements may be recovered through biological and chemical reactions in the water column and thus be included in the aquatic trophic web ${ }^{4}$. Re-suspension of sediments may cause release of trace elements back into the water column, posing as potential threat to the ecosystem ${ }^{5}$. Although some metals can be considered essential elements for living organisms, even those can become toxic when environmental concentrations are increased ${ }^{6}$. The presence of metals in the environment may have a natural or anthropogenic origin. Among the anthropogenic sources wastewater, discharges, agricultural runoff, air pollutants, deposition and specific environmental accidents are the most important ${ }^{1,2,7}$.

In aquatic systems metals are distributed as colloidal species which are water soluble, and as materials in suspension and in sediments. Metal concentrations in sediments and in river waters can be easily altered by deposition and remobilization processes. Heavy metals have a propensity to adsorb from aqueous phases to fine suspended particles and are transported along the water course, where they can pose a health risk to benthic organisms if toxic levels are reached, resulting in lower taxonomic diversity, lower reproduction rate, reduced growth or even death ${ }^{8,9}$. According to Filgueiras, ${ }^{10}$ not even $1 \%$ of the pollutants released in water remain in the aqueous phase; the rest are deposited in sediments. Since sediment is an important sink for heavy metals that contaminate the water and acts as a habitat and important food source for aquatic biota, its quality provides essential information to assess the pollution status of aquatic ecosystem, as it reflects the long term status ${ }^{8}$.

Mercury and arsenic discharged into the aquatic environment can damage aquatic species, ecosystems and consumers due to their toxicity and cumulative behavior ${ }^{11}$. Once released into the environment, metals can be present in soils, sediments and waters, due to their persistence and possible bioaccumulation in biota ${ }^{1}$. Elevated concentrations of certain metals in fish, such mercury and arsenic, are of public concern because of the well-documented health risks associated with consuming fish with high metal burdens (Canadian Food Inspection agency (CFIA) ${ }^{12}$.

Arsenic is one of the most important metalloids in the environment due to its known toxicity and its association with several types of cancer ${ }^{13,14}$. The abundance of As in our planet is on the order of 1.5 to $3 \times 10^{4} \mathrm{mg} \cdot \mathrm{Kg}^{-115}$.
Soils in the northern as well as in the central area of Chile exhibit high arsenic content, which is mainly associated with copper deposits. An important arsenic source in central Chile has been the copper mining processes ${ }^{16,17}$.

Mercury is of particular concern because of its documented toxicity, persistence in the in the aquatic environment, high potential for bioaccumulation in the aquatic food web and ability to biomagnify with increasing trophic levels ${ }^{18}$. The impact arises from the wide variety of sources (anthropogenic and natural). Artisanal and small-scale gold mining (ASGM) is the sector with largest demand for mercury ${ }^{19}$, and therefore one of the major sources of $\mathrm{Hg}$ input to the environment ${ }^{20}$. The estimated annual mercury emission from ASGM is approximately $800-1000$ tons, of which approximately $50 \%$ comes from Latin American operations including Chile ${ }^{21}$.

Mercury and arsenic accumulate in organisms at the bottom of the aquatic food chain and are biomagnified up the food chain, reaching the highest concentrations in top predator fish. It is generally accepted that consumption of fish and seafood is one of the major sources of exposure to mercury and arsenic for humans ${ }^{22,23}$, hence it is important to investigate the levels of mercury and arsenic in fish to assess whether the concentration of mercury and arsenic is within the permissible limits and will not pose a hazard for human consumption.

Given the great importance of hydrology, alterations in the flow of rivers caused by humans have serious consequences ${ }^{24}$; there is increasing recognition that anthropogenic changes in rivers such as construction of dams, river diversions and channel modifications have significant long-term consequences for water supply, water quality, aquatic ecosystems and sediment budgets ${ }^{25}$. ${ }^{26}$. One of the most dramatic and widespread impacts of humans on the natural environment are dams ${ }^{27}$. It has been estimated that in the world there are presently around 45,000 dams with water column depth of more than 15 meters 28 .

Considering that there are dams in a number of rivers in Chile producing disruption of free water flow, and that mineral salts may accumulate in the zone of the dam ${ }^{29}$, in this study we examine the content of As and $\mathrm{Hg}$ in components of the water system; water, sediments and fishes in the affluent and effluent of five reservoirs, Cogotí (1939), Recoleta (1934), Corrales (2001), La Paloma (1959 - 1966) and Rapel (1968), selected according to their date of construction, which is given in the parentheses.

The aims of this study were: i) Optimize and validate the methodology to determine total As and $\mathrm{Hg}$ in fresh water systems. ii) Study the influence of two zones (affluent and effluent) of five reservoirs in the content of As and $\mathrm{Hg}$, in superficial water, interstitial water, sediment and different tissues of two fish species selected as models; the benthic catfish (Trichomycterus areolatus) and the pelagic silverside (Basilichthys microlepidotus), during high flow (winter 2010) and low flow (summer 2011). iii) Assess whether concentrations of As and $\mathrm{Hg}$ present a risk to the use of water from reservoirs for irrigation, if the 
sediment is a source of contamination for biota and whether fish species present a risk for human consumption.

\section{MATERIALS AND METHODS}

\subsection{Experimental design}

A series of experiments were performed to optimize the analysis conditions for each matrix using a minimum number of experiments. Each design was performed using the Statgraphics Centurion XV software. A fractionated mixed level experimental design $\left(3 \cdot 2^{4-2}\right)$ was performed with 3 centers with a total of 15 experiments.

Five variables were considered in the design for arsenic: $\% \mathrm{w} / \mathrm{v} \mathrm{KI}, \% \mathrm{w} / \mathrm{v}$ ascorbic acid, \%w/v $\mathrm{NaBH}_{4}, \% \mathrm{v} / \mathrm{v} \mathrm{HCl}$ and Flow Ratio (Sample/Reagent (2 $\mathrm{mL})$.

Five variables were considered in the design for mercury: $\mathrm{mL}$ of concentrated $\mathrm{H}_{2} \mathrm{SO}_{4}, \mu \mathrm{L} \mathrm{KMnO}_{4} 5 \%$ w/v, \% w/v $\mathrm{SnCl}_{2}, \% \mathrm{v} / \mathrm{v} \mathrm{HCl} \mathrm{mL}$ and Flow Ratio (Sample/Reagent $(2 \mathrm{~mL})$ ).

2.1 Selection of reservoirs and sampling sites
Five reservoirs with different uses and date of construction were selected: Cogotí ( $\left.31^{\circ} 00^{\prime} \mathrm{S}, 71^{\circ} 05^{\prime} \mathrm{W}\right)$; Corrales $\left(31^{\circ} 54^{\circ} \mathrm{S}, 70^{\circ} 54^{\prime} \mathrm{W}\right)$; La Paloma ( $30^{\circ} 44^{\prime} \mathrm{S}$, $71^{\circ} 00^{\prime} \mathrm{W}$ ); Rapel ( $\left.34^{\circ} 08^{\prime} \mathrm{S}, 7^{\circ} 29^{\prime} \mathrm{O}\right)$ and Recoleta $\left(30^{\circ} 28^{\prime} \mathrm{S}, 71^{\circ} 06^{\prime} \mathrm{W}\right.$ ). Superficial water of these reservoirs was sampled during two seasons, winter 2010 and summer 2011, along with interstitial water, sediments and two species of fish, the benthic catfish (Trichomycterus areolatus) and the pelagic silverside (Basilichthys microlepidotus). Three sampling sites were selected in each reservoir in the effluent (above the dam) and three sites in the effluent (below the dam). All coordinates were recorded using a GPS system.

\section{2 Sampling}

Sediment sampling was performed according to sediment protocol ${ }^{30}$. Water sampling was performed according to the procedure of NCh 411/6 Of. $98^{31}$. Fish sampling was performed using electric fishing, which affects the chosen sampling points as it must be possible to use it. The equipment used was an electrical signal converter SAMUS $-725 \mathrm{M}$ of $15 \mathrm{~V}$ and maximum power output of 600 volts. Individuals collected were euthanized with tricaine methanosulfonate (MS222) at a concentration of $250 \mathrm{mgL}^{-1}$. The samples are detailed in the following table.

Table 1. Fish collected in winter 2012 (high flow) and summer 2011 (low flow) (C= catfish; $\mathrm{S}=$ silverside)

\begin{tabular}{|c|c|c|c|c|c|c|c|c|c|c|c|}
\hline \multirow{3}{*}{ Season } & \multirow{3}{*}{ Zone } & \multicolumn{10}{|c|}{ Reservoirs } \\
\hline & & \multicolumn{2}{|c|}{ Cogotí } & \multicolumn{2}{|c|}{ Corrales } & \multicolumn{2}{|c|}{ La Paloma } & \multicolumn{2}{|c|}{ Rapel } & \multicolumn{2}{|c|}{ Recoleta } \\
\hline & & $\mathrm{C}$ & $\mathbf{S}$ & $\mathrm{C}$ & $\mathbf{S}$ & $\mathrm{C}$ & $\mathbf{S}$ & $\mathrm{C}$ & $\mathbf{S}$ & $\mathrm{C}$ & $\mathbf{S}$ \\
\hline \multirow{2}{*}{ High Flow } & Affluent & 5 & 6 & 5 & 4 & 6 & 4 & 4 & 4 & 4 & 4 \\
\hline & Effluent & 7 & 7 & 4 & 4 & 4 & 6 & 0 & 0 & 0 & 5 \\
\hline \multirow{2}{*}{ Low Flow } & Affluent & 6 & 9 & 0 & 0 & 6 & 6 & 11 & 12 & 5 & 6 \\
\hline & Effluent & 10 & 11 & 5 & 7 & 0 & 7 & 15 & 0 & 0 & 4 \\
\hline
\end{tabular}

\section{3Characterization in situ}

Samples of surface water and sediments were measured for $\mathrm{pH}, \mathrm{EC}$ and Eh using a multiparameter 340i. They were stabilized with Suprapur $\mathrm{HCl}$ to $\mathrm{pH} \leq 2$. Sediment samples were allowed to decant, then the aqueous phase was extracted (interstitial or pore water) by simple filtration with a Munktell paper disc. Once the interstitial water was extracted, the sediment was dried at room temperature. Finally sediments were screened, separating two fractions: $2 \mathrm{~mm}$ and $0.063 \mathrm{~mm}$. The interstitial water extracted was stabilized with $\mathrm{HC}$ Suprapur to $\mathrm{pH} \leq 2$.

In the laboratory the samples of catfish and silverside were dissected, extracting three tissues: gills, liver and muscle. Each part separately was deposited in a $10 \mathrm{~mL}$ beaker, and dried in an oven at $40 \pm 2^{\circ} \mathrm{C}$ to constant mass.

2.4 Acid digestion by microwave

Digestion of solid samples (sediments and fish) was performed in microwave equipment MarsXpress 5 equipped with Teflon-coated PFA $55 \mathrm{~mL}$ Kevlar tubes with protected sleeves. $250 \mathrm{mg}$ of dry solid sample was poured into microwave tubes; $10 \mathrm{~mL}$ of $\mathrm{HNO}_{3}$ Suprapur Merck was added. They were allowed to stand for $15 \mathrm{~min}$. For the fish samples, the digestion program was : $1600 \mathrm{~W}$ power; power percentage $65 \%$; time $15 \mathrm{~min}$.; temperature $200{ }^{\circ} \mathrm{C}$; maintenance 15 min., cool 15 minutes (EPA 3015-A) ${ }^{32}$. For sediment, the digestion program was based on the EPA 3051 method ${ }^{33,}$ : Power $800 \mathrm{~W}$; power percentage $100 \%$; time $11 \mathrm{~min}$; temperature $175^{\circ} \mathrm{C}$; maintenance 15 min., cool 15 minutes. Then the digested samples were diluted 10 times in flasks with deionized water Milli.-Q grade, and stored at $4{ }^{\circ} \mathrm{C}$ until analysis.

\subsection{Standard preparation}

Optimal solutions according to the experimental design (Table 2) were used to prepare arsenic samples.

Table 2. Experimental variables optimized for arsenic determination in different matrices.

\begin{tabular}{|l|c|c|c|}
\hline \multicolumn{1}{|c|}{ Factor } & Water & Fish & Sediment \\
\hline$\% \mathrm{p} / \mathrm{v} \mathrm{KI}$ & 5.8 & 6.1 & 6.7 \\
\hline$\% \mathrm{p} / \mathrm{v} \mathrm{Ascorbic} \mathrm{acid}$ & 10 & 10 & 5.5 \\
\hline$\% \mathrm{p} / \mathrm{v} \mathrm{NaBH} 4$ & 2.0 & 2.0 & 0.2 \\
\hline$\% \mathrm{v} / \mathrm{v} \mathrm{HCl}$ & 14 & 1,0 & 15 \\
\hline Flow $(\mathrm{mL} \mathrm{sample/} 2 \mathrm{~mL}$ Regents $)$ & 3.0 & 1.0 & 1.0 \\
\hline
\end{tabular}

Optimal solutions according to the experimental design (Table 3) were used to prepare samples of mercury.

Table 3. Experimental variables optimized for mercury determination in different matrices.

\begin{tabular}{|c|c|c|c|}
\hline Factors & Water & Fish & Sediment \\
\hline $\mathrm{mL} \mathrm{H}_{2} \mathrm{SO}_{4}(\mathrm{c})$ & 0.8 & 0.9 & 0.8 \\
\hline$\mu \mathrm{L} \mathrm{KMnO}_{4} 5 \% \mathrm{p} / \mathrm{v}$ & 151 & 200 & 192 \\
\hline$\% \mathrm{p} / \mathrm{v} \mathrm{SnCl}_{2}$ & 0.5 & 0.5 & 5.0 \\
\hline$\% \mathrm{v} / \mathrm{v} \mathrm{HCl}$ & 0.6 & 0.5 & 5.0 \\
\hline Flow (mL sample/ 2 mL Regents) & 2.0 & 1.0 & 1.0 \\
\hline
\end{tabular}

\subsection{Experimental conditions}

The reagents specified in Tables 2 and 3 were added to samples of surface and interstitial water, sediment and fish tissues, and then samples were homogenized, diluted to $10 \mathrm{~mL}$ and measured immediately. A Shimadzu atomic absorption spectrophotometer A 6800 model with hydride generator HVG -1 was used. As: $\lambda=193.7 \mathrm{~nm}$ and $\mathrm{Hg}: \lambda=250.7 \mathrm{~nm}$.

\subsection{Determination of total arsenic}

For the determination of arsenic the reactions involved are: In the hydride generator:

$$
\mathrm{NaBH}_{4}+3 \mathrm{H}_{2} \mathrm{O}+\mathrm{HCl} \rightarrow \mathrm{H}_{3} \mathrm{BO}_{3}+\mathrm{NaCl}+8 \mathrm{H}^{*}
$$

Hydride formation:

$$
\mathrm{As}^{+3}+8 \mathrm{H}^{*} \rightarrow \mathrm{AsH}_{3}+\frac{5}{2} \mathrm{H}_{2}(\text { excess })
$$

\subsection{Determination of total $\mathrm{Hg}$}

For the determination of mercury the reactions involved are: Pre-Oxidation:

$$
\mathrm{Hg}^{+}+\mathrm{MnO}_{4}^{-}+4 \mathrm{H}^{+}+2 e^{-} \stackrel{\mathrm{H}_{2} \mathrm{SO}_{4}}{\longrightarrow} \mathrm{Hg}^{+2}+\mathrm{MnO}_{2}+2 \mathrm{H}_{2} \mathrm{O}
$$

$\mathrm{Hg}^{0}$ formation:

$$
\mathrm{Hg}^{+2}+\mathrm{Sn}^{+2} \stackrel{\mathrm{H}^{+}}{\longrightarrow} \mathrm{Hg}^{0}+\mathrm{Sn}^{+4}
$$


The spectrophotometer records the absorbance of arsenic in the form of arsine (Eq. 2) and mercury vapor in its elemental state (Eq. 4).

\section{RESULTS AND DISCUSSION}

\subsection{Validation of the analytical method}

The following parameters were considered to validate the methods used: accuracy, linear range, sensitivity, calibration curves, precision, detection and quantification limits (LOD and LQD). The following table (Table 4), shows the linear range for determination of $\mathrm{As}$ and $\mathrm{Hg}$, as well as the regression coefficients of the respective calibration curves. Calibration curves were showed that the magnitude of the slope changed in the following order: water, sediment and fish for As and $\mathrm{Hg}$. After producing the calibration curves, we proceeded to analyze three certified reference samples (of known concentration) on different days, obtaining the results in \%CV shown in Table 4. As shown in the values of standard deviations from Table 4 , all under $5 \%$, which indicates that the determination of total $\mathrm{Hg}$ and $\mathrm{As}$ in the various matrices is precise.

Table 4. Linear range and $\% \mathrm{CV}$ of $\mathrm{As}$ and $\mathrm{Hg}$ in different matrices

\begin{tabular}{|c|c|c|c|c|c|c|}
\hline \multirow{2}{*}{ Matrices } & \multicolumn{3}{|c|}{ As } & \multicolumn{3}{|c|}{$\mathbf{H g}$} \\
\hline & Range $\left(\mu \mathrm{gL}^{-1}\right)$ & $\mathbf{R}^{2}$ & $\% \mathrm{CV}$ & Range $\left(\mu g L^{-1}\right)$ & $\mathbf{R}^{2}$ & $\% \mathrm{CV}$ \\
\hline Water & $0.10-4.7$ & 0.999 & 3.50 & $0.001-0.1$ & 0.995 & 2.00 \\
\hline Fish & $0.10-7.1$ & 0.998 & 4.10 & $0.030-5.0$ & 0.997 & 4.90 \\
\hline Sediment & $0.10-12$ & 0.999 & 2.70 & $0.051-0.4$ & 0.999 & 3.40 \\
\hline
\end{tabular}

Accuracy was determined by the recovery rate obtained in the analysis of certified reference samples (water: ERM- CA615; Fish: DOLT- 4; Sediments: BCR- 320R). The accuracy was evaluated by the percentage of recovery. Recovery for arsenic was: water $97 \pm 4.3 \%$; fish $95 \pm 6.1 \%$ and sediment 109 $\pm 0.5 \%$. Recovery for mercury was: water $100 \pm 6.4 \%$; fish $95 \pm 0.1 \%$ and sediment $102 \pm 5.7 \%$. All percentages of recovery obtained have less than $5 \%$ error. All values were in the range $95-110 \%$, so the method has good accuracy.

The limit of detection (LOD) was calculated as three times the average standard deviation of ten blanks and the slope of the analytical curve. For the limit of quantification (LQD), the LOD was multiplied by 10 . The LQD of arsenic were $0.15\left(\mu \mathrm{gL}^{-1}\right)$ for water, Fish 0.74 and sediments $0.58\left(\mathrm{mgkg}^{-1}\right)$. For mercury: water $0.07\left(\mu \mathrm{gL}^{-1}\right)$; fish 0.74 and sediments $0.30\left(\mathrm{mgkg}^{-1}\right)$. The lowest detection limit was found for $\mathrm{Hg}$ in water, while the highest limit was found for $\mathrm{As}$ and $\mathrm{Hg}$ in fish.

The following tables show the arsenic and mercury concentrations in different matrices.

\subsubsection{Arsenic and mercury in sediment}

Table 5. Arsenic and mercury concentration in sediment $\left(\mathrm{mgkg}^{-1}\right)$ in high flow and low flow, affluent and effluent of five reservoirs. Each value is the mean of six replicates; $<\mathrm{DL}=$ below detection limit; ${ }^{*}=$ no samples.

\begin{tabular}{|c|c|c|c|c|c|c|}
\hline \multicolumn{7}{|c|}{ As } \\
\hline Seasons & Zones & Cogotí & Corrales & La Paloma & Rapel & Recoleta \\
\hline \multirow{2}{*}{ High Flow } & Affluent & 0.67 & 0.64 & 0.04 & 0.98 & 0.04 \\
\hline & Effluent & 0.56 & 0.04 & 0.05 & 0.72 & 0.02 \\
\hline \multirow{2}{*}{ Low flow } & Affluent & 0.04 & $*$ & 0.04 & 0.03 & 0.04 \\
\hline & Effluent & 0.02 & 0.03 & 0.06 & 0.03 & 0.04 \\
\hline \multicolumn{7}{|c|}{$\mathrm{Hg}$} \\
\hline Seasons & Zones & Cogotí & Corrales & La Paloma & Rapel & Recoleta \\
\hline \multirow{2}{*}{ High Flow } & Affluent & 0.260 & 0.006 & $<\mathrm{DL}$ & 0.012 & 0.005 \\
\hline & Effluent & $<\mathrm{DL}$ & 0.006 & $<\mathrm{DL}$ & 0.052 & $<\mathrm{DL}$ \\
\hline \multirow{2}{*}{ Low flow } & Affluent & $<\mathrm{DL}$ & $*$ & 0.003 & 0.010 & 0.005 \\
\hline & Effluent & $<\mathrm{DL}$ & 0.001 & 0.005 & $<\mathrm{DL}$ & $<\mathrm{DL}$ \\
\hline
\end{tabular}

The concentrations of $\mathrm{Hg}$ were generally lower than those of As in the same reservoirs and zones. The concentrations found during the low flow season were lower than those of the high flow season; this is because there were much greater flow and dilution effects in the latter. In the summer campaign (low flow), no large variation in arsenic concentrations was observed between reservoirs and zones. For the winter season (high flow), however, the values varied between 0.04 and $0.98 \mathrm{mg} \mathrm{kg}^{-1}$ in the affluent and $0.02-0.56 \mathrm{mg} \mathrm{kg}^{-1}$ in the effluent. The highest concentrations were in the reservoirs Cogotí, Corrales and Rapel. The Recoleta and La Paloma reservoirs showed lower concentrations in both zones.

$\mathrm{Hg}$ concentrations found during the winter high flow season were higher than those of the summer low flow season. In the low flow season concentrations in effluents decreased in the Recoleta, Corrales and Cogotí reservoirs especially in the effluent, while the opposite behavior was observed in Rapel reservoir. In the La Paloma reservoir the highest concentration was found in low flow season in the affluent. The concentrations ranged from $<\mathrm{DL}$ to $0.26 \mathrm{mgkg}^{-1}$, with the highest concentration in the affluent of Cogotí reservoir.

Studies of heavy metal concentration in sediments of dams are scarce 
${ }^{34}$, thus a better comparison of $\mathrm{As}$ and $\mathrm{Hg}$ concentration could be with those concentrations found in some rivers. Recent studies in the Ebro River basin (Spain) found that concentration of As in sediments ranged between 0.43- 1.15 $\mathrm{mg} \mathrm{kg}{ }^{-1}$ while mercury was not detected in the 12 stations along the river ${ }^{35}$, and in the Thigithe River (Tanzania) As concertation was from $<$ DL to $520 \mathrm{mg}$ $\mathrm{kg}^{-1}$ and $\mathrm{Hg}$ ranged from $<\mathrm{DL}$ to $0.37 \mathrm{mg} \mathrm{kg}^{-1}$ in five sites ${ }^{36}$. Studies in São Francisco River basin (Brazil), found As concentrations ranged between 1.86 to $309 \mathrm{mg} \mathrm{kg}^{-1}$ while the concentration of $\mathrm{Hg}$ ranged between 2.04 to 0.036 in the 28 sites studied ${ }^{37}$. In the Bortala River (China) ${ }^{38}$ As concentration ranged from 3.27 to $10.34 \mathrm{mg} \mathrm{kg}^{-1}$ and $\mathrm{Hg} 0.01$ to $1.69 \mathrm{mg} \mathrm{kg}^{-1}$ in eight sites studied.

The concentration of $\mathrm{Hg}$ in the Chilean reservoirs in this study was generally in accordance with the lower limits of the rivers mentioned above, while the concentration of As was relatively similar to those found in the Ebro river basin; however, values were very different and lower than in some sites of the other rivers, probably due to a strong anthropic source in these rivers.

3.2.2 Arsenic and mercury in water

Table 6. Arsenic and mercury concentration in surface water (SW) and interstitial water (IW) $\left(\mu \mathrm{g} \mathrm{L}^{-1}\right)$. Each value is the mean of six replicates; $<\mathrm{DL}=$ below detection limit; ${ }^{*}=$ no samples.

\begin{tabular}{|c|c|c|c|c|c|c|c|c|c|c|c|}
\hline \multicolumn{12}{|c|}{ As } \\
\hline Seasons & Zones & \multicolumn{2}{|c|}{ Cogotí } & \multicolumn{2}{|c|}{ Corrales } & \multicolumn{2}{|c|}{ La Paloma } & \multicolumn{2}{|c|}{ Rapel } & \multicolumn{2}{|c|}{ Recoleta } \\
\hline & & SW & IW & SW & IW & SW & IW & SW & IW & SW & IW \\
\hline \multirow{2}{*}{ High Flow } & Affluent & 1.8 & 25 & 2.2 & 11 & 3.2 & 33 & $*$ & 17 & 1.2 & 3.1 \\
\hline & Effluent & 3.9 & 22 & 2.6 & 6.3 & 1.8 & 12 & $*$ & 3.2 & 1.5 & 6.7 \\
\hline \multirow{2}{*}{ Low flow } & Affluent & 4.7 & 54 & * & $*$ & 1.6 & 14 & 5.30 & 14.0 & 3.0 & 13 \\
\hline & Effluent & 5.1 & 5.5 & 2.4 & 7.7 & 1.4 & 33 & 4.10 & 6.30 & 4.5 & 14 \\
\hline \multicolumn{12}{|c|}{$\mathrm{Hg}$} \\
\hline Seasons & Zones & \multicolumn{2}{|c|}{ Cogotí } & \multicolumn{2}{|c|}{ Corrales } & \multicolumn{2}{|c|}{ La Paloma } & \multicolumn{2}{|c|}{ Rapel } & \multicolumn{2}{|c|}{ Recoleta } \\
\hline \multirow{2}{*}{ High Flow } & Affluent & 0.03 & 0.04 & $<\mathrm{DL}$ & 0.06 & $<\mathrm{DL}$ & 0.04 & $*$ & 0.06 & 0.02 & 0.03 \\
\hline & Effluent & $<\mathrm{DL}$ & 0.04 & $<\mathrm{DL}$ & 0.03 & $<\mathrm{DL}$ & 0.04 & $*$ & 0.06 & $<\mathrm{DL}$ & $<\mathrm{DL}$ \\
\hline \multirow{2}{*}{ Low flow } & Affluent & $<\mathrm{DL}$ & 0.07 & $*$ & $*$ & 0.02 & 0.01 & 0.04 & 0.05 & 0.03 & 0.01 \\
\hline & Effluent & $<\mathrm{DL}$ & 0.04 & $<\mathrm{DL}$ & 0.04 & $<\mathrm{DL}$ & 0.04 & $<\mathrm{DL}$ & 0.05 & 0.02 & $<\mathrm{DL}$ \\
\hline
\end{tabular}

Comparison of the surface and interstitial water shows that the concentrations of arsenic and mercury found in surface water were lower than the interstitial water this is because the latter is in direct contact with the sediment which is a sink of heavy metals. For As in superficial water there was a wide variation in the concentrations found between reservoirs and zones, and a small increase in the concentrations of As in the low flow campaign. The highest concentration was observed in the effluent of La Paloma during the high and flow season in interstitial water.

During both seasons the concentrations in the effluent decreased in the Rapel and Cogotí reservoirs, while in La Paloma and Recoleta reservoirs this decrease occurred in the tributary. Corrales dam in the winter season showed the same behavior as Cogotí and Rapel, while for the summer season this behavior could not be established due to lack of samples in the tributary. Mercury was in very low concentration and no differences were found between reservoirs, zones or seasons.

There are few studies of the concentration of heavy metals and metalloids in interstitial or pore water, however their determination is very important because the interstitial water is the interface between surface water and sediment, which may indicate a relationship in terms of the mobility of metals from the sediment into the water column and their interaction with the biota ${ }^{39}$. Studies in the Ebro River basin (Spain) ${ }^{35}$ found that in the 12 sites studied, As concentrations in pore water ranged between 3.62 to $35.9 \mu \mathrm{gL}^{-1}$, while $\mathrm{Hg}$ was found between 0.08 to $1.27 \mu \mathrm{gL}^{-1}$. Concentrations of both As and $\mathrm{Hg}$ found in our study are in agreement with these results, especially As, while for $\mathrm{Hg}$ concentrations found in the Ebro River were slightly higher .

The concentration of heavy metals and metalloids in the surface water of rivers is mainly due to the movement of water, oxygenation and $\mathrm{pH}$ variables that determine the existence of water-soluble species. Recent work in the Yellow River (China) ${ }^{40}$ showed that the average of As concentrations ranged from 0.1 to $1.7 \mu \mathrm{gL}^{-1}$ and for $\mathrm{Hg}$ concentrations ranged from 0.03 to $0.06 \mu^{-1}$ in 5 reservoirs sites studied (108 samples), while in the Thigihe River (Tanzania) ${ }^{36}$; As concentrations ranged from $<\mathrm{LD}$ to $1.1 \mu \mathrm{gL}^{-1}$ and $\mathrm{Hg}$ ranged from $<$ LD to 0.3 in 5 sites studied. A study in the water of Lake Atitalán (Guatemala) found As of 7.7 to $107.0 \mu \mathrm{gL}^{-1}$ and concentrations of $\mathrm{Hg}$ ranged between $<$ DL to $8.2 \mu \mathrm{gL}^{-1}$ in 14 sites $^{41}$.

A large number of mines, mainly gold and copper, and a small number of iron and manganese mines are located in the northern Chilean basins. Rivers with more mining activities are expected to have high concentrations of heavy metals. Concentration of As in 12 Chilean rivers studied between the years 1987 to 2008 ranged between 483.6 to $6.0 \mu \mathrm{gL}^{-1}$ and $\mathrm{Hg}$ ranged from 281.0 to $3.0 \mu \mathrm{gL}^{-142}$. The values found in our study are consistent with the ranges found for $\mathrm{As}$ and $\mathrm{Hg}$ in some rivers such as reservoirs in Yellow River in China ${ }^{40}$. However, our values are significantly lower concentrations of $\mathrm{As}$ and $\mathrm{Hg}$ found in the five reservoirs and both areas than those found in the Chilean rivers studied.

\subsubsection{Arsenic in fish}

For the catfish As was detected in all organs and in both zones except in the effluent of Rapel and Recoleta in high flow and the affluent of Corrales and effluents of La Paloma and Recoleta in low flow, because no samples were collected (Table 1). Concentrations ranged from $48.0 \mathrm{mgkg}^{-1}$ dry weight in gills (Rapel effluent) to $0.5 \mathrm{mgkg}^{-1}$ dry weight in gills (Cogotí effluent). For the silverside As was detected in all organs in both areas, except in the effluent of Rapel in high flow and the affluent of Corrales and effluent of Rapel in low flow, because no samples were collected (Table 1); concentrations ranged from $152.6 \mathrm{mgkg}^{-1}$ dry weight in gills (Corrales effluent) and $<\mathrm{LD}$ in muscle (Corrales and La Paloma effluent). 
Table 7. Arsenic concentration ( $\mathrm{mgkg}^{-1}$ dry weigh), in catfish and silverside; A) high flow and B) low flow seasons. Each value is the mean of six replicates; $<\mathrm{DL}=$ below detection limit; ${ }^{*}=$ no samples.

\begin{tabular}{|c|c|c|c|c|c|c|c|}
\hline \multicolumn{2}{|c|}{} & \multicolumn{3}{c|}{ Catfish } & \multicolumn{3}{c|}{ Silverside } \\
\hline \multirow{2}{*}{ Reservoirs } & Zone & Gill & Liver & Muscle & Gill & Liver & Muscle \\
\hline \multirow{3}{*}{ Cogotí } & Affluent & 4.6 & 5.9 & 5.0 & 8.2 & 10.3 & 7.4 \\
\cline { 2 - 9 } & Effluent & 0.5 & 5.0 & 4.9 & 5.5 & 3.1 & 9.1 \\
\hline \multirow{3}{*}{ Corrales } & Affluent & 12.5 & 8.0 & 11.3 & 4.9 & 3.5 & 4.3 \\
\cline { 2 - 9 } & Effluent & 5.9 & 3.4 & 2.8 & 2.6 & 1.2 & 3.1 \\
\hline \multirow{3}{*}{ La Paloma } & Affluent & 9.1 & 12.2 & 9.2 & 10.8 & 6.5 & 10.3 \\
\cline { 2 - 9 } & Effluent & 0.6 & 9.6 & 7.8 & 2.9 & 0.1 & 2.5 \\
\hline \multirow{3}{*}{ Rapel } & Affluent & 6.6 & 12.7 & 7.8 & 0.5 & 0.5 & 0.5 \\
\cline { 2 - 9 } & Effluent & $*$ & $*$ & $*$ & $*$ & $*$ & $*$ \\
\hline & Affluent & 6.9 & 6.4 & 9.6 & 1.6 & 1.5 & 2.4 \\
\cline { 2 - 9 } & Effluent & $*$ & $*$ & $*$ & 1.4 & 1.7 & 1.1 \\
\hline
\end{tabular}

\begin{tabular}{|c|c|c|c|c|c|c|c|}
\hline \multicolumn{2}{|c|}{ B) } & \multicolumn{3}{|c|}{ Catfish } & \multicolumn{3}{|c|}{ Silverside } \\
\hline Reservoirs & Zone & Gill & Liver & Muscle & Gill & Liver & Muscle \\
\hline \multirow{2}{*}{ Cogotí } & Affluent & 15.8 & 8.0 & 19.2 & 6.8 & 16.3 & 11.4 \\
\hline & Effluent & 19.5 & 22.2 & 29.3 & 18.5 & 26.6 & 18.2 \\
\hline \multirow{2}{*}{ Corrales } & Affluent & $*$ & $*$ & $*$ & $*$ & $*$ & $*$ \\
\hline & Effluent & 31.2 & 23.5 & 33.8 & 152.6 & 144.2 & $<\mathrm{DL}$ \\
\hline \multirow{2}{*}{ La Paloma } & Affluent & 21.2 & 15.4 & $<\mathrm{DL}$ & 28.6 & 11.7 & 31.4 \\
\hline & Effluent & $*$ & $*$ & $*$ & 22.7 & 36.3 & $<\mathrm{DL}$ \\
\hline \multirow{2}{*}{ Rapel } & Affluent & 35.7 & 24.5 & 27.0 & 48.0 & 23.4 & 31.5 \\
\hline & Effluent & 48.0 & 23.4 & 31.5 & $*$ & $*$ & $*$ \\
\hline \multirow{2}{*}{ Recoleta } & Affluent & 30.6 & 18.5 & 20.7 & 32.0 & 17.6 & 28.7 \\
\hline & Effluent & $*$ & $*$ & $*$ & 15.2 & 19.9 & 26.5 \\
\hline
\end{tabular}

\subsubsection{Mercury in fish}

The concentrations of $\mathrm{Hg}$ in the catfish were below the detection limit in most reservoirs and zones, except in the affluent of Cogotí and Rapel in the high flow season; $\mathrm{Hg}$ was found in all the organs. In low flow seasons $\mathrm{Hg}$ was found in the effluent of Cogotí in gills and in the affluent of Rapel affluent in gills and liver, while in the affluent of Recoleta $\mathrm{Hg}$ was found only in gills. The concentrations of $\mathrm{Hg}$ in the silverside were below the detection limit in most reservoirs and zones, except in the Cogotí affluent in high flow season in gills and muscle and in the affluent of Cogotí in all the organs. In the low flow season $\mathrm{Hg}$ was found in liver and muscle in the affluent of Cogotí and Recoleta. The overall concentration of $\mathrm{Hg}$ in catfish was higher in the low flow season.

The overall concentration of $\mathrm{As}$ and $\mathrm{Hg}$ in catfish and silverside was higher in the low flow season, probably due to concentration effect due to the decreasing flow of the reservoirs. Arsenic and mercury have been determined in various fish species in different rivers and oceans ${ }^{43-46}$. A study in four sites in Argentina found concentrations of $\mathrm{As}$ and $\mathrm{Hg}$ in muscle of silverside (Odontesthes bonariensis) that ranged from 0.03 to $0.76 \mathrm{mgkg}^{-1}$ wet weight for As and from 0.03 to $0.42 \mathrm{mgkg}^{-1}$ wet weight for $\mathrm{Hg}^{47}$. In muscle of Chilean the silverside species (Basilichthys microlepidotus) in this study (Tables 7 and 8) concentrations of As and $\mathrm{Hg}$ were significantly higher in the most of reservoirs and zones than those of $O$. bonariensis, although the comparison is relative because in our study concentrations of As and $\mathrm{Hg}$ in Basilichthys microlepidotus are expressed in dry weight while Odontesthes bonariensis concentrations are expressed in wet weight.

Another study determined As and $\mathrm{Hg}$ concentrations in muscle, gill and liver in Labeo victoriamus from Thigithe river (Tanzania) ${ }^{36}$; in this study As concentration in muscle ranged from 0.25 to 2.5 and $\mathrm{Hg}$ ranged from 0.1 to
$0.7 \mathrm{mgkg}^{-1}$ dry weight; in gill As concentration ranged between 1.0 to 5.0 and $\mathrm{Hg} 0.04$ to $0.15 \mathrm{mgkg}^{-1}$ dry weight; in liver As concentration ranged between 0.1 to $7.8 \mathrm{mgkg}^{-1}$ dry weight and $\mathrm{Hg}<\mathrm{DL}$ to $0.3 \mathrm{mgkg}^{-1}$ dry weight. Tables 7 and 8 show that the concentrations of $\mathrm{As}$ and $\mathrm{Hg}$ we found were higher in the most of reservoirs and zones, indicating that there is bioaccumulation and biomagnification of As and $\mathrm{Hg}$ in the organs of fish species studied.

Mollusks, crustaceans and other marine organisms that live in contaminated environments and are a source of human food are known accumulators of heavy metals and metalloids in their tissues. They have the ability to regulate the concentration of the element within the cell and accumulate excess in nontoxic form. This is the case for As, which is usually ingested as a more toxic inorganic chemical species and is converted by the body into arsenosugar or arsenobetaine, one of the most abundant species in aquatic organisms, which are less toxic compounds ${ }^{48}$. The situation of $\mathrm{Hg}$ is opposite to that of $\mathrm{As} ; \mathrm{Hg}$ is accumulated in the tissues of fish and bivalves usually as methyl mercury, more toxic, while the source that supplies is usually the less toxic inorganic mercury ${ }^{49}$.

Metallothioneins are involved in the homeostasis mechanism of an aquatic organism in which a toxic element participates. One of the most important roles of these proteins is protecting the cell in the presence of a toxic element that penetrates the cell ${ }^{50}$. This very important, because seafood is an effective way to ingest toxic chemicals which can cause adverse effects on human health. Because of this, government authorities in most countries limit the daily intake of metals in food by setting maximum limits. 
Table 8. Mercury concentration ( $\mathrm{mgkg}^{-1}$ dry weight) in catfish and silverside A): high flow and B) low flow season. Each value is the mean of six replicates; $<$ DL $=$ below detection limit; ${ }^{*}=$ no samples

\begin{tabular}{|c|c|c|c|c|c|c|c|}
\hline \multicolumn{2}{|c|}{ A } & \multicolumn{3}{c|}{ Catfish } & \multicolumn{3}{c|}{ Silverside } \\
\hline \multirow{2}{*}{ Reservoirs } & Zone & Gill & Liver & Muscle & Gill & Liver & Muscle \\
\hline \multirow{2}{*}{ Cogotí } & Affluent & 3.5 & 18.7 & 3.1 & 21.8 & $<\mathrm{DL}$ & 22.5 \\
\cline { 2 - 9 } & Effluent & $<\mathrm{DL}$ & 12.1 & $<\mathrm{DL}$ & $<\mathrm{DL}$ & $<\mathrm{DL}$ & $<\mathrm{DL}$ \\
\hline \multirow{3}{*}{ Corrales } & Affluent & $<\mathrm{DL}$ & $<\mathrm{DL}$ & $<\mathrm{DL}$ & $<\mathrm{DL}$ & $<\mathrm{DL}$ & $<\mathrm{DL}$ \\
\cline { 2 - 9 } & Effluent & $<\mathrm{DL}$ & $<\mathrm{DL}$ & $<\mathrm{DL}$ & $<\mathrm{DL}$ & $<\mathrm{DL}$ & $<\mathrm{DL}$ \\
\hline \multirow{3}{*}{ La Paloma } & Affluent & $<\mathrm{DL}$ & $<\mathrm{DL}$ & $<\mathrm{DL}$ & $<\mathrm{DL}$ & $<\mathrm{DL}$ & $<\mathrm{DL}$ \\
\cline { 2 - 9 } & Effluent & $<\mathrm{DL}$ & 12.7 & $<\mathrm{DL}$ & $<\mathrm{DL}$ & $<\mathrm{DL}$ & $<\mathrm{DL}$ \\
\hline \multirow{2}{*}{ Rapel } & Affluent & 15.8 & 7.4 & 16.7 & 8.2 & 6.3 & 24.7 \\
\cline { 2 - 9 } & Effluent & $*$ & $*$ & $*$ & $*$ & $*$ & $*$ \\
\hline \multirow{2}{*}{ Recoleta } & Affluent & $<\mathrm{DL}$ & $<\mathrm{DL}$ & $<\mathrm{DL}$ & $<\mathrm{DL}$ & $<\mathrm{DL}$ & $<\mathrm{DL}$ \\
\cline { 2 - 9 } & Effluent & $*$ & $*$ & $*$ & $<\mathrm{DL}$ & $<\mathrm{DL}$ & $<\mathrm{DL}$ \\
\hline
\end{tabular}

\begin{tabular}{|c|c|c|c|c|c|c|c|}
\hline \multicolumn{2}{|c|}{ B } & \multicolumn{3}{c|}{ Catfish } & \multicolumn{3}{c|}{ Silverside } \\
\hline \multirow{2}{*}{ Reservoirs } & Zone & Gill & Liver & Muscle & Gill & Liver & Muscle \\
\hline \multirow{3}{*}{ Cogotí } & Affluent & $<\mathrm{DL}$ & $<\mathrm{DL}$ & $<\mathrm{DL}$ & $<\mathrm{DL}$ & 5.8 & 3.9 \\
\cline { 2 - 9 } & Effluent & 0.6 & $<\mathrm{DL}$ & $<\mathrm{DL}$ & $<\mathrm{DL}$ & $<\mathrm{DL}$ & $<\mathrm{DL}$ \\
\hline \multirow{3}{*}{ Corrales } & Affluent & $*$ & $*$ & $*$ & $*$ & $*$ & $*$ \\
\cline { 2 - 9 } & Effluent & $<\mathrm{DL}$ & $<\mathrm{DL}$ & $<\mathrm{DL}$ & $<\mathrm{DL}$ & $<\mathrm{DL}$ & $<\mathrm{DL}$ \\
\hline \multirow{3}{*}{ La Paloma } & Affluent & $<\mathrm{DL}$ & $<\mathrm{DL}$ & $<\mathrm{DL}$ & $<\mathrm{DL}$ & $<\mathrm{DL}$ & $<\mathrm{DL}$ \\
\cline { 2 - 9 } & Effluent & $*$ & $*$ & $*$ & $<\mathrm{DL}$ & $<\mathrm{DL}$ & $<\mathrm{DL}$ \\
\hline \multirow{3}{*}{ Rapel } & Affluent & 1.4 & 33.5 & $<\mathrm{DL}$ & 5.9 & $<\mathrm{DL}$ & $<\mathrm{DL}$ \\
\cline { 2 - 9 } & Effluent & 10.5 & $<\mathrm{DL}$ & $<\mathrm{DL}$ & $*$ & $*$ & $*$ \\
\hline \multirow{2}{*}{ Recoleta } & Affluent & 33.8 & $<\mathrm{DL}$ & $<\mathrm{DL}$ & $<\mathrm{DL}$ & 53.9 & 18.6 \\
\cline { 2 - 9 } & Effluent & $*$ & $*$ & $*$ & $<\mathrm{DL}$ & $<\mathrm{DL}$ & $<\mathrm{DL}$ \\
\hline
\end{tabular}

\subsection{Regulation and toxicity}

There are no regulations in Chile to control the quality of sediments, so they refer to the standards set by the NWQMS Canada in $2000^{51}$, which set benchmarks according to the biological effect that pollutants generate in aquatic systems. The criteria to consider a sediment toxic are defined in the sediment quality guidelines (SQG), which provide thresholds to determine if the concentration of any of the metals present in the sediments may involve risk for aquatic organisms and consequently for human health. Threshold effect concentrations (TEC) and their probable effect concentrations (PEC) for sediment levels were reported by MacDonald et al., $2000^{52}$. TEC corresponds to the concentration below which no adverse effects are observed on benthic organisms. The PEC intends to identify the contaminant concentrations above which harmful effects on benthic organisms are expected to occur frequently. The levels $\left(\mathrm{mgkg}^{-1}\right)$ established for As are TEC 9.8 and PEC 33, while for $\mathrm{Hg}$ they are TEC 0.2 and PEC 1.1. Considering the limits set by the regulations, the concentrations of As and $\mathrm{Hg}$ found in sediment would not have a toxic effect on the biota except for $\mathrm{Hg}$ in the affluent of Cogotí reservoir, high flow season $\left(0.260 \mathrm{mgkg}^{-1}\right)$ which exceeded TEC values.

According to $\mathrm{NCH} 1333$ Of. $78^{53}$, for irrigation water As values should not exceed $0.10 \mathrm{mgL}^{-1}$, so almost all the waters of the reservoirs studied comply with the standard. $\mathrm{Hg}$ values should not exceed $0.0010 \mathrm{mgL}^{-1}$, so all reservoirs studied comply with this standard.

To assess the public health risk of fish consumption, in this study we compared metal levels in muscle (Tables 7 and 8 ) with the maximum permissible limits for human consumption (MPL) established by different organizations. The international standards of the Commission of the European Communities 2006; MAFF 1995; FAO / WHO $2004{ }^{54-56}$ consider that the maximum permissible limit for consumption of fish muscle for $\mathrm{Hg}$ is $0.5 \mu \mathrm{gg}{ }^{-1}$ and for As $6.0 \mu \mathrm{gg}^{-1}$ wet weight, and $1.0 \mu \mathrm{gg}^{-1}$ according FAO/WHO 2004 and
Australian (ANZFA), $1998^{57,58}$; these values are considered in muscle because it is the consumable part. For comparison to the data mentioned as dry weight, they were converted to wet weight using a factor 0.3 ; since moisture is usually about $70 \%$ in muscle ${ }^{59}$.

In this study in reservoirs and zones and for both fish species the $\mathrm{Hg}$ concentration detected exceeds the standard, with maximum values of 6.75 and $7.41 \mathrm{ggg}^{-1}$ wet weight for silverside in affluent of Cogotí and affluent of Rapel, respectively, in high flow season, and $5.58{\mu \mathrm{gg}^{-1}}^{-1}$ wet weight in the affluent of Recoleta, while As in most of dams and zones and for both fish species exceeded Commission of the European Communities, FAO/WHO and ANZFA rules with higher values in the low flow season. In this season all the values exceeded $6.0 \mu \mathrm{gg}^{-1}$ wet weight.

\section{CONCLUSIONS}

The validated analytical method and experimental design with reference material permitted determination of $\mathrm{As}$ and $\mathrm{Hg}$ in different matrices: sediment, surface water, interstitial water and different tissues of two fish species, obtaining results of analytical quality.

No significant effect of reservoirs and zones in the content of As and $\mathrm{Hg}$ was observed. However, Arsenic (As), was found in higher concentrations in the different matrices of the five reservoirs and zones.

According to the $\mathrm{As}$ and $\mathrm{Hg}$ concentrations found in water it could be used as irrigation water, because they do not exceed Chilean Standard 1333; the concentrations of As and $\mathrm{Hg}$ found in sediment would not have a toxic effect on the biota, except for $\mathrm{Hg}$ in the affluent of Cogotí Reservoir in the high flow season $\left(0.260 \mathrm{mgkg}^{-1}\right)$ which exceeded the TEC values.

The catfish tended to bioaccumulate higher levels of both arsenic and mercury. This is attributed to this species living in the vicinity of the sediment, 
which is consistent with the values found in the sediment and the interstitial water that were higher than superficial water.

As and $\mathrm{Hg}$ concentrations found in muscle of both species exceeded the International Limit for Human Consumption.

\section{ACKNOWLEDGEMENTS}

The authors are grateful to Fondecyt Project 1100341 and Proyecto Enlace Universidad de Chile 2013. DV thanks Basal Grant PFB 023 and ICM P05002 .

\section{REFERENCES}

1. A. Maceda-Veiga, M. Monroy, A. de Sostoa, Ecotoxicol. Enriron. Saf. 76, 93, (2012).

2. M. Ricard, H. Guasch, D. Barcdeló, R. Brix, H.M. Conceicão, A. Geizinger, J. Hydrol. 383, 52, (2010).

3. N. Roig, J. Sierra, I. Moreno-Garrido, E. Nieto, E. Pérez, m. Schumacher, J. Blasco, Sci. Total Environ. 540, 287, (2016).

4. K. Nemati, N.K.A. Bakar, M. R. Abas,. E. Sobhanzadeh, J. Hazard. Mater. 192, 402, (2011).

5. J.Y. Yi, Z.F. Yang, S.H. Zhang, Environ. Pollut. 159, 2575, (2011)

6. M.C. Newnan, Fundamentals of Ecotoxicology. 2009. Third ed. CRC Press 9781420067040

7. A. Suárez-Serrano, C. Alcaraz, C. Ibañéz,. R. Trobajo, C. Barata, Ecotoxicol. Environ. Saf. 73, 280, (2010).

8. U.P. Nasir, P. S. Harikumar, J. Environ. Prot. 2, 710, (2011).

9. A.E. Ogbeibu, M.O. Omoigberale, I. M. Ezenwa, J.O. Eziza, J.O. Igwe, Nat. Environ. 2, 1, (2014).

10. A.V. Filgueiras, I. Lavilla, C. Bendicho, Sci. Total Environ. 330, 115, (2004).

11. M. Tuzen, Food and Chemical Toxicology, 47, 1785, (2009).

12. Canadian Food Inspection Agency (CFIA). Fish products standards and methods manual. Appendix 3 Canadian Guidelines for Chemical Contaminants and Toxins in fish and fish Products, 2014.

13. N. L. Saint-Jaques, L. Parker, P. Brown, T. J. Dummer, Environ. Health Global Access. Sci. Sour, 13, (2014).

14. E. Bustaffa, S. Stoccoro, F.Bianchi, L. Mugliore, Arch. Toxicol., 88, 1043, (2014).

15. B. K. Mandal, K. T. Suzuki, Talanta, 58, 201, (2002).

16. J. Narváez, P. Richter, M. I. Toral, J. Environ. Qual. 20, 522, (2007).

17. L. Ascar, I. Ahumada, P. Richter, Chemosphere, 70, 1211, (2008).

18. P. A. Cott, B. A. Zajdlik,. M.J. Palmer, M. D. McPherson, Journal of Greak Lakes Research, 42, 223, (2016).

19. UNEP, Mercury: Time to act. United Nations Environment Programme, Geneva. 44 p. ISBN 978-92-807-3310-5. DTI/1623/GE. (2013).

20. M.M. Cordy, I. Veiga, S. Salih, S. Al-Saadi, O. Console,. L. Garcia, P. Mesa, M. Velásquez-Lopéz, Roeser, A. Sci. Total Environ. 410, 154, (2011).

21. J.J. Hinton, M.M. Veiga, A.T. Veiga, J. Claner Prod., 11, 99, (2003).

22. H. Agah, M. Leemarkers, Y. Gao, S. M. Fatemi, M. M. Katal, W. Baeyens, Environmental Monitoring Assessment, 169, 203, (2010).

23. M. Alina, A. Azrina, A. S. Mohd Yunus, S. Mohd Zakiuddin, H. Mohd Izuan,. R. Effendi, R. Muhammad Rizal, International Food Research Journal, 19, 135, (2012).

24. D. L. Saunders, J. J. Meeuwing, A. C. J. Vincent, Conserv. Biol. 16, 30, (2002).

25. F. J. Gottgens, J. E. Evans, J. Great Lakes Res., 2, 87, (2007).

26. W. L. Graf, Water Resources Res., 35, 1305, (1999).

27. M. Dynesius, C. Nilsson, C. Science, 266, 753, (1994).

28. C. Nilsson, C. A. Reidy, M. Dynesius, C. Revenga, Science. 308, 405, (2005).

29. K. W. Thorton, B. L. Kimmel, F. E. Payne, eds. Reservoir Limnology: Ecological perspectives. John Wiley \& Sons, Inc., Somerset, New Jersey, 1990, pp 246-256.

30. S. I. Simpson, G. E. Batley, A. A. S. Charlston, J. L. Dtauber, C. K. King, J. C. Chapman, R. V. Hyne, S. A. Gale, A. C. Roach, W. A. Maher, J. Sharyan. J, Handbook for Sediment Quality Assessment, (CSIRO Bangor, NSW), 2005, pp 9-19,

31. Norma Chilena Oficial, NCh 411/6, Of. 98, Calidad del agua-Muestreo Parte 6: Guía para el muestreo de ríos.

32. EPA Method 3015A, Microwave assisted acid digestion of aqueous samples and extracts, (2007).
33. EPA Method 3051, Microwave assisted acid digestion of sediments, sludges, soils, and oils, (1994).

34. S. V.Copaja, V R. Nuñez, G. S. Muñoz, G. L.González, I. Vila, D. Véliz, J. Chil. Chem. Soc., 60, 2642, (2016)

35. N. Roig, J. Sierra, I. Moreno-Garrido, E. Nieto, E Pérez Gallego, M. Schumacher, J. Blasco, Sc. Total Environ. 540, 287. (2016).

36. G. R. Mataba, V. Verhaert, R. Blust, L. Bervoets, Sc. Total Environ. 547, 48. (2016).

37. P.S. Rezende, P.A.S. Moura, W.A. Durão, Jr. Clésia, C. Nascente, C.C. Windmöller, L.M. Costa, J. Braz. Chem. Soc. 22, 910, (2011).

38. Z. Zhang, Li Juying, Z. Mamat, Y. QingFu, Ecotoxicol. Environ Saf., 126, 94, (2016).

39. S.V. Copaja, G.S. Muñoz, V.R. Nuñez, C. Pérez, I. Vila, D. Véliz. Bull. Environ. Contam. Toxicol. 97 (1), 24, (2016).

40. W. Hou, S. Sun, M. Wang, X. Li, N. Zhang, X. Xin, L. Sun, W. Li, R. Jia, Ecological Indicators, 61, 309, (2016).

41. F. Pérez Sabino, B. Valladares Jovel, E. Hernández, B. Oliva, M. Cid, P. Jayes Reyes, Ciencia, Tecnología y Salud, 2, 37, (2015).

42. J. Pizarro, P.M. Vergara, J.A. Rodríguez, A. M. Valenzuela, J. Hazardous Materials, 181, 747, (2010).

43. B. V. González, J.J. Schultze, Ciencias Marinas, 32, 439, (2006).

44. Kh. M. El-Moselhy, A. I. Othman, H. Abd. El-Azem, M.E.A. El-Metwally, Egipcian Journal of Basic and Applied Sciences, 1, 97 (2014).

45. M. Stancheva, m.L. Makedonski, E. Petrova, Bulgarian Journal of Agricultural Sciences, 19, 30, 2013

46. J. Valdés, D. Román, M. Guiñéz, L. Rivera, J. Ávila, P. Cortés, A. Castillo, Marine Pollution Bulletin, 100, 544, (2015).

47. E. Avigliano, N. F. Schenone, A. V. Volpedo, W. Goessler, A. Fernández Cirelli, Sc. Total Environ. 506-507, 102. (2015).

48. Slejkovec, Z. AR. Byne, A.R. Smodis, B. Fresenius J. Anal Chem. 354, 592 (1996).

49. Díaz, O. Encina, F. Chuecas, L. Becerra, J. Cabello, J. A. Figueroa, A. Muñoz. F. Rev Biol. Mar Aceanogr 36, 15 (2001).

50. Viarengo, A.. Noti J.A. Comp Biocehm Physiol 104, 355 (1993).

51. National Water Quality Management Strategy (NWQMS), Australian and new Zealand guidelines for fresh and marine water quality. 2. Aquatic Ecosystems Rationale and Background Information, Cap 8. 2000.

52. D. D. MacDonald, C. Ingersoll, T. Berger, Arch. Environ. Contam. Toxicol., 39, 20, (2000).

53. Norma Chilena Oficial, NCh 1333 Of. 1978, Requisitos de calidad del agua para diferentes usos.

54. Commission of the European Communities (2006). Commission regulation (EC). $\mathrm{N}^{\circ} 1881 /$ of 19 December 2006 setting maximum levels for certain contaminants in foodstuffs. Official Journal of the European Union. The commission of the European communities, Brussels, L364-5/L364-24.

55. MAFF (1995). Monitoring and surveillance of non-radiactive contaminants in the aquatic environment and activities regulating the disposal of wastes at sea, 1993. Aquatic environment Monitoring report $\mathrm{N}^{\circ} 44$. Lowestoft: Directorate of Fisheries Research.

56. FAO/WHO (2004). List of maximun levels recommended for contaminants by the Joint FAO/WHO Codex Alimentarius commision.

58. ANZFA (1998). Food Standards code. Standard A12, Issue 37. Australia, New Zealand Food Authority, Australian government publishing service.

59. Abdallah MAM., Egypt. Journal Mar Syst, 73, 114, (2008). 